\title{
Metallothioneins pattern during ontogeny of coastal dolphin, Pontoporia blainvillei, from Argentina
}

\author{
P.S. Polizzi ${ }^{\mathrm{a}, \mathrm{b}, *}$, M.B. Romero ${ }^{\mathrm{a}, \mathrm{b}}$, L.N. Chiodi Boudet ${ }^{\mathrm{a}}$, K. Das ${ }^{\mathrm{c}}$, P.E. Denuncio ${ }^{\mathrm{a}, \mathrm{d}}$, D.H. Rodríguez ${ }^{\mathrm{b}, \mathrm{d}}$, \\ M.S. Gerpe ${ }^{\mathrm{a}, \mathrm{b}}$ \\ ${ }^{a}$ Toxicología Ambiental, Instituto de Investigaciones Marinas y Costeras (IIMyC), Facultad de Ciencias Exactas y Naturales, Universidad Nacional de Mar del Plata, Funes 3350, \\ (CP. 7600) Mar del Plata, Argentina \\ ${ }^{\mathrm{b}}$ Consejo Nacional de Investigaciones Científicas y Técnicas (CONICET), Argentina \\ ${ }^{\mathrm{c}}$ Laboratory for Oceanology - MARE Center B6c, University of Liege, Liege 4000, Belgium \\ ${ }^{\mathrm{d}}$ Biología, Ecología y Conservación de Mamíferos Marinos, Departamento de Ciencias Marinas, IIMyC, Facultad de Ciencias Exactas y Naturales, Universidad Nacional de Mar del \\ Plata, Argentina, Funes 3350, CP. 7600 Mar del Plata, Argentina
}

\section{A R T I C L E I N F O}

Keywords:

Pontoporia blainvillei

Metallothioneins

Biomarker

Ontogeny

Trace elements

Heavy metals

\begin{abstract}
A B S T R A C T
Metallothioneins are signals of metal exposure and widely used in biomonitoring. Franciscana dolphin is an endemic cetacean from the Southwestern Atlantic Ocean, classified as Vulnerable A3d by the IUCN. Metallothionein, copper and zinc in Franciscana were assessed in two geographic groups; one inhabits La Plata River estuary, anthropogenically impacted, and the other inhabits marine coastal ecosystems, with negligible pollution. Despite the environment, hepatic and renal MT concentrations were similar, but there was a declining trend from early to later developmental stages. Metallothionein $\mathrm{K} / \mathrm{L}, \mathrm{Cu}$ and $\mathrm{Zn}$ levels corresponded to normal reported ranges. MT was not related with $\mathrm{Cd}$. Fetal concentrations were higher than its mother. These results and the health status of dolphins are suggesting that MT correspond to physiological ranges for the species, and they are closely to homeostasis of $\mathrm{Zn}$ and $\mathrm{Cu}$, according to its ontogenetic changes. The information constitutes the first MT information on Franciscana dolphin and can be considered as baseline for the species conservation.
\end{abstract}

(c) 2014 Published by Elsevier Ltd.

\section{Introduction}

Biomarkers are successful in identifying contaminated areas and potential chemical stressors. They can be characterized as functional measures of exposure to stress, which are usually expressed at the sub organism level of biological organization. These responses are useful to establish absence of significant biological or ecological effects at the population, community or ecosystem level (Adams et al., 2001).

Metallothioneins (MTs) are low-molecular weight proteins (6000-7000 Da), rich in cysteine ( $>30 \%)$ that bind metals and are found in all animal phyla. The sulphydryl groups $(-\mathrm{SH})$ of this aminoacid bind divalent cations such as cadmium, zinc, copper and mercury (Hylland et al., 1994). Therefore, these proteins play a primary role in the homeostasis of essential metals, such as copper $(\mathrm{Cu})$ and zinc $(\mathrm{Zn})$. However, non-essential metals, particu-

\footnotetext{
* Corresponding author at: Toxicología Ambiental, Instituto de Investigaciones Marinas y Costeras (IIMyC), Facultad de Ciencias Exactas y Naturales, Universidad Nacional de Mar del Plata, Funes 3350, CP. 7600 Mar del Plata, Argentina. Tel.: +54 $2234752426 \times 455$.

E-mail addresses: ppolizzi@mdp.edu.ar (P.S. Polizzi), mabelenromero@gmail.com (M.B. Romero), leilachiodi@gmail.com (L.N. Chiodi Boudet), krishna.das@ulg.ac.be (K. Das), pdenunci@mdp.edu.ar (P.E. Denuncio), dhrodri@gmail.com (D.H. Rodríguez), msgerpe@mdp.edu.ar (M.S. Gerpe).
}

larly cadmium (Cd), are also able to induce MT synthesis (Amiard et al., 2006; Roesijadi, 1996). Because these characteristics, MTs have been regarded as an indicator of metal exposure, and widely used as a tool for biomonitoring programs.

Franciscana dolphin (Pontoporia blainvillei) (Gervais and d'Orbigny, 1844),is a small and endemic dolphin in the Southwestern Atlantic Ocean. Its geographic distribution ranges from Itaúnas $\left(18^{\circ} 25^{\prime} \mathrm{S}, 30^{\circ} 42^{\prime} \mathrm{W}\right.$, Brazil, Siciliano, 1994$)$ to Golfo Nuevo $\left(42^{\circ} 35^{\prime} \mathrm{S}\right.$, $64^{\circ} 48^{\prime} \mathrm{W}$, Argentina, Bastida et al., 2007). The International Union for Conservation of Nature (IUCN) has classified the species as Vulnerable A3d throughout its geographical range (Reeves et al., 2012), due to the population decline of more than 30\% over three generations, with 2000-3000 dolphins incidentally captured in fishing nets each year. Because of its vulnerability as bycatch, $P$. blainvillei has been considered the most impacted small cetacean in the Southwestern Atlantic Ocean (Secchi and Wang, 2002).

Based on mitochondrial deoxyribonucleic acid (DNA), and morphometric and population parameters, Secchi et al. (2003) proposed four Management Areas for Franciscana dolphin. These areas correspond to two coastal zones in Brazilian waters (Areas I and II), one zone along the coast of southern Brazil and Uruguay (Area III), and one zone in Argentine waters (Area IV) (Fig. 1). Recently, available information on home range (Bordino et al., 2008), population genetics (Mendez et al., 2008, 2010) and toxicology 


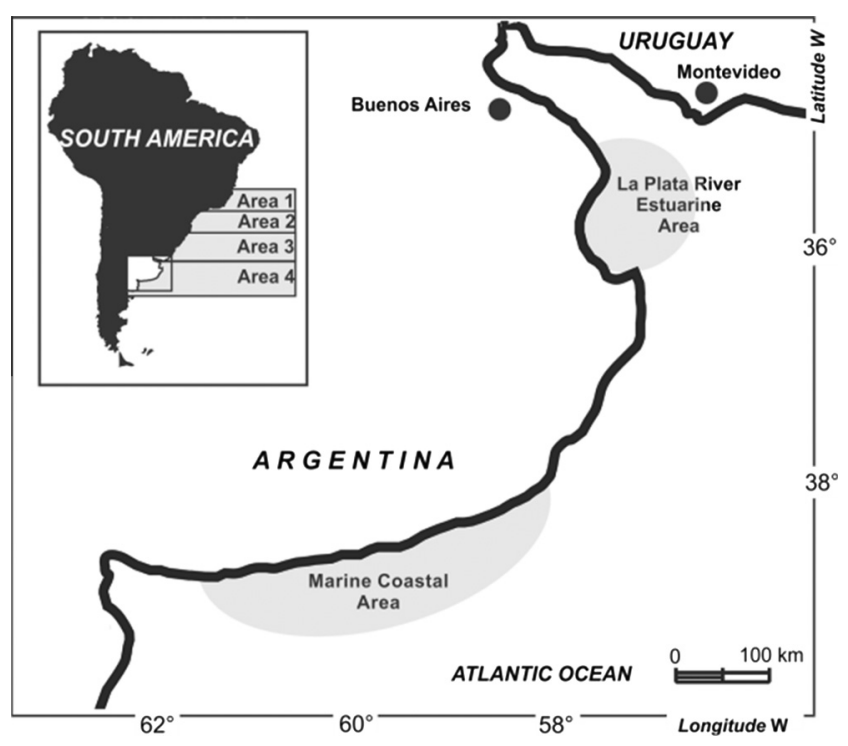

Fig. 1. Marine and estuarine bycatch areas of Franciscana dolphin, Pontoporia blainvillei, in Argentine shelf waters.

(Polizzi et al., 2013) suggest discrete stockes within Area IV. Within this zone, and along the coast of Buenos Aires Province, two main ecosystems occur: the La Plata River estuary and the marine coast south of the estuary (Fig. 1).

The estuarine area is influenced by most urban and industrial waste, and effluents are discharged into the river without treatment (Carsen et al., 2003), due to large cities such as Buenos Aires and La Plata (Argentina), and Montevideo (Uruguay), which have more than 15 million residents. In contrast, the marine coastal area is unaffected by the contaminated estuarine waters. Some of the major tourist cities of Argentina are located in this area, but they produce a minor environmental impact on the marine coast.

Therefore, the aims of this study were to assess the levels of MTs and the ontogenetic pattern in liver and kidney of $P$. blainvillei from two areas with different impact; and to evaluate the role of MTs as biomarker of environmental stress in top predators.

\section{Materials and methods}

\subsection{Study area and sampling}

Franciscana dolphins ( $n=55$, Fig. 1 ) were collected from two coastal areas of Buenos Aires Province (northern Argentina): the La Plata River estuary (environment with recognized impact) being the "estuarine geographical group of species" $(n=27)$, and the marine coast area (environment with low or null impact) at the south of the estuarine zone being the "marine geographical group" $(n=28)$ Table 1 . Three stillborn fetuses (umbilical cord remnants) and one pair of mother-fetus were included in the "marine geographical group".

All the dolphins were incidentally capture in fishing nets being entangled for a period less than $10 \mathrm{hs}$ until sampling. To assess the body condition, the Relative Index of Body Condition (Kn) of Le Cren (1951, Recorded Body weight/Estimated Body Weight) was calculated. The estimated weight was obtained from the lengthweight curve using the following equation previously published (Rodríguez et al., 2002):

Body Weight $(\mathrm{kg})=0.0005 *$ Body Length $(\mathrm{cm})^{2.2222}$

Before necropsy, total length, weight and sex were determined for each dolphin (Fig. 1). Samples of liver and kidney were collected,
Table 1

Fine scale age (year) range for age class of Franciscana dolphins from marine and estuarine geographic groups. $n=$ number of dolphin.

\begin{tabular}{llllll}
\hline & \multicolumn{2}{l}{ Marine dolphins } & & \multicolumn{2}{l}{ Estuarine dolphins } \\
\cline { 2 - 3 } \cline { 5 - 6 } \cline { 5 - 6 } & $n$ & Estimated age range & & $n$ & Estimated age range \\
\hline Fetus & 1 & - & & 3 & - \\
Calves & 1 & 0.1 & & 11 & $0.1-0.6$ \\
Juveniles & 17 & $1.1-3.3$ & & 9 & $1.1-3.4$ \\
Adults & 9 & $3.6-7.9$ & & 6 & $3.5-10.5$ \\
\hline
\end{tabular}

immediately frozen in liquid nitrogen and stored at $-80^{\circ} \mathrm{C}$ until analysis.

\subsection{Age determination and fine scale adjustments to decimal year}

Age was determined by Dr. Denuncio (Polizzi et al., 2013) using Growth Layer Groups (GLGs) in dentine and cementum dental layers, and each GLG was considered to be one year (Pinedo and Hohn, 2000). Harrison et al. (1981) and Kasuya and Brownell (1979) found that peak calving for Franciscana occurs in November in Uruguay. In Argentine waters, based on chronological information of newly born, calving occurs from early October to early February with a peak in November (Denuncio et al., 2013). On the basis of this information, we used mid-November as the mean birth date for calves to estimate the fine scale age (by month).

According to maturity, Franciscana dolphins were classified into four categories:

- Fetus: one dolphin found in the womb, and two stillborns.

- Calves: suckling (only milk in their stomachs), mix diet (milk and solid prey), and weaned (only solid prey) dolphins with age less than one year (Kasuya and Brownell, 1979; Rodríguez et al., 2002; Denuncio et al., 2013).

- Juveniles (sexually immature): 1-3.5 years old (Kasuya and Brownell, 1979; Panebianco et al., 2012).

- Adults (sexually mature): 3.5 onwards (Kasuya and Brownell, 1979).

\subsection{Metallothionein assay}

The MT assay was performed according to the spectrometric method described by Viarengo et al. (1997). The absorbance was read at $412 \mathrm{~nm}$, and MTs concentration was quantified using reduced glutathione (GSH) as a reference standard. The amount of MTs was calculated based on cysteine content in rabbit (18 cysteines $/ \mathrm{mol}$ ), assuming a similar SH group content in Franciscana dolphin MTS. All samples were analyzed in triplicate, blanck were performed and the MTS concentration was reported as nmol MT per gram of wet tissue.

\section{4. $\mathrm{Cu}$ and $\mathrm{Zn}$ assay}

Lyophilized liver and kidney samples were accurately weighted to the nearest $0.1 \mathrm{mg}$ and were subjected to microwave-assisted digestion in Teflon ${ }^{\mathrm{TM}}$ vessels with $2 \mathrm{ml} \mathrm{HNO}_{3}$ (65\%), $1 \mathrm{ml} \mathrm{H}_{2} \mathrm{O}_{2}$ (30\%) and $5 \mathrm{ml}$ of $18.2 \mathrm{M} \Omega \mathrm{cm}$ deionized water. After cooling, samples were diluted to $50 \mathrm{ml}$ with $18.2 \mathrm{M} \Omega \mathrm{cm}$ deionized water in a volumetric flask. $\mathrm{Cu}$ and $\mathrm{Zn}$ levels were determined by inductively coupled plasma mass spectroscopy (ICP-MS, PerkinElmer, Sciex, DCR 2). An internal standard $\left({ }^{103} \mathrm{Rh}\right.$, CertiPUR ${ }^{\circledR}$, Merck) was added to each sample and calibration standard solutions. Quality control and quality assurance included field blanks, method blanks, and CRMs - DORM-2 and DOLT-3. Recovery of Cu y Zn in CRMs ranged from $85 \%$ to $100 \%$, averaging $90 \pm 5 \%$. The reported concentrations for both elements are expressed on a wet weight basis in ng/g. Dry 
weight conversion were performed according Yang and Miyazaki (2003).

\subsection{Statistical analysis}

Homoscedasticity of data was checked with Levene test $(p<0.05)$. Statistical differences were checked by parametric (Student- $t$ or One factor ANOVA), or non-parametric (Mann Whitney) tests. All analyses were conducted with the software STATISTICA ${ }^{\circledR}$ 6.0 (Statsoft, Inc.).
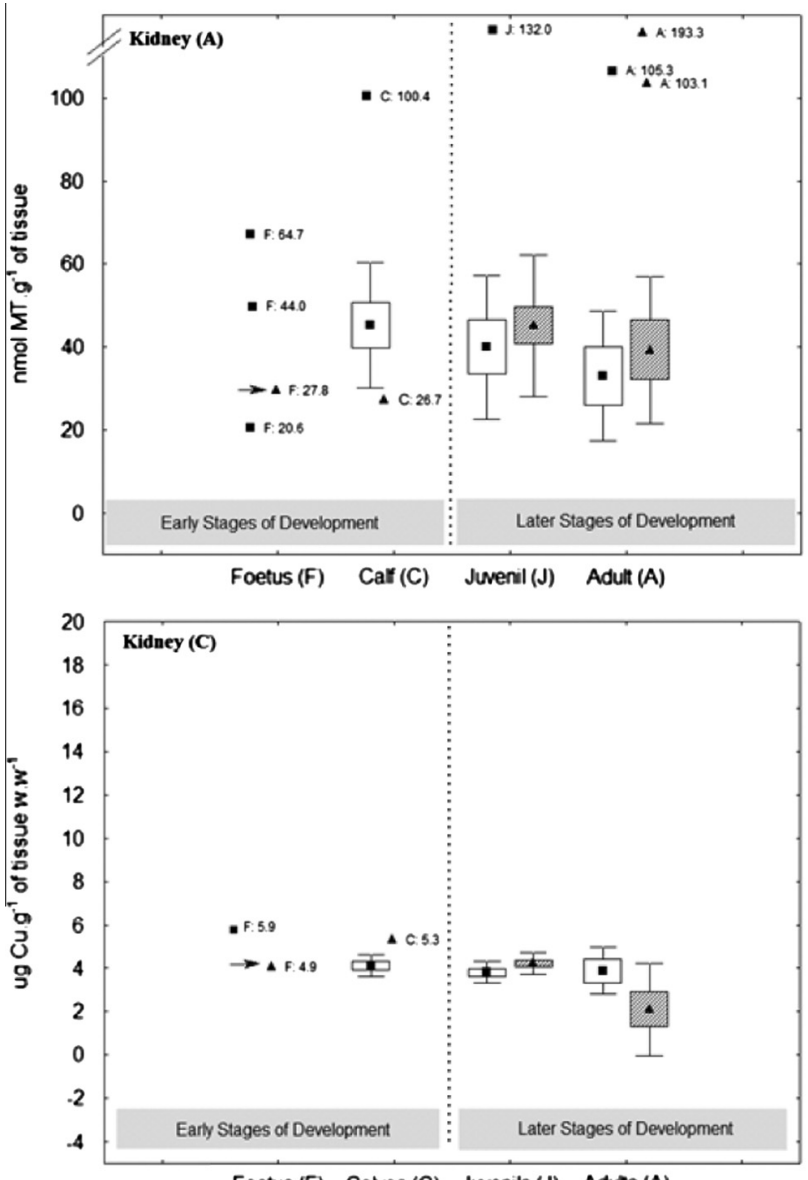

Foetus (F) Calves (C) Juvenils (J) Aduts (A)

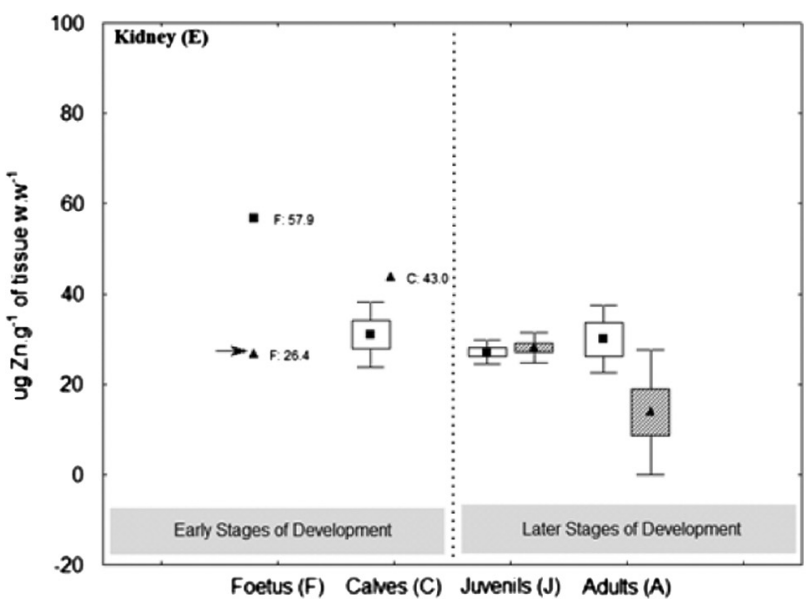

\section{Results}

The Relative Index of Body Condition (Kn) varied from 0.73 to 1.37 , and both estuarine $(0.95 \pm 0.11)$ and marine $(1.05 \pm 0.10)$ dolphins presented values very close to 1.00 , with no indication of an impoverished condition.

The concentrations of MTs, $\mathrm{Zn}$ and $\mathrm{Cu}$ in liver and kidney of the two studied geographic groups of Franciscana dolphins are showed in Fig. 2. They are presented by age classes, without distinction of sexes, due to the absence of significant differences between them

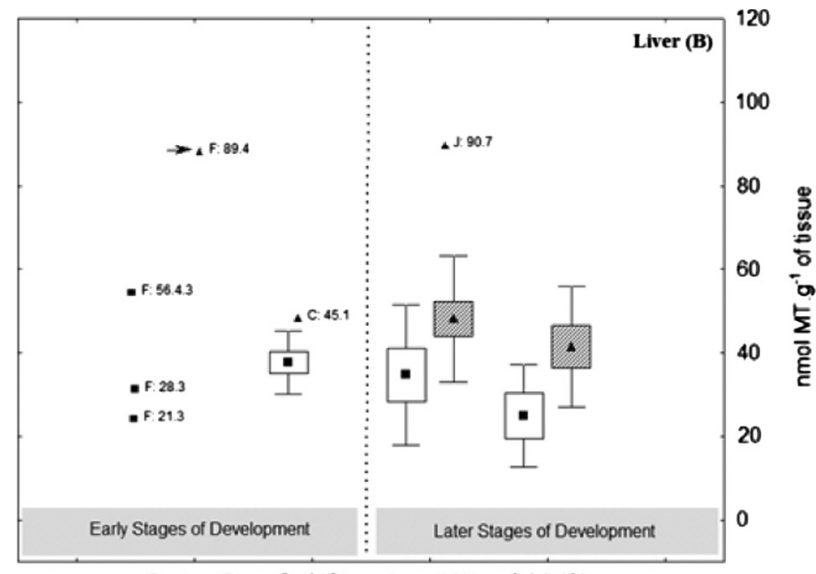

Foetus (F) Carf (C) Juvenil (J) Adult (A)

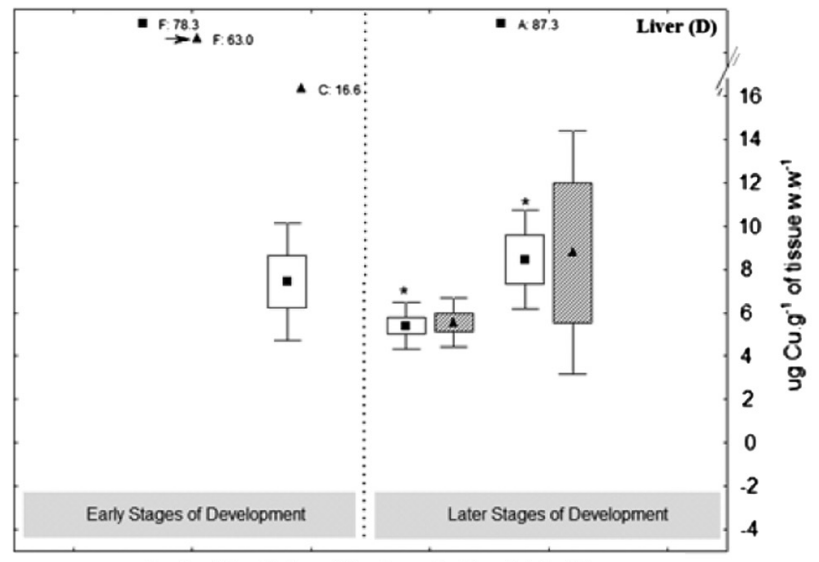

Foetus (F) Calves (C) Juvenils (J) Adults (A)



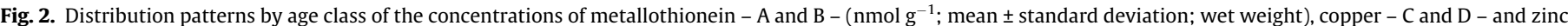

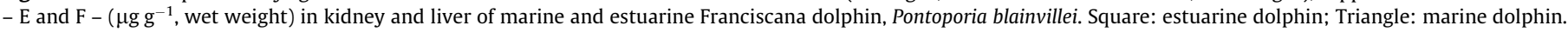
Arrow: fetus found in the womb. Asterisk: significant differences between age classes.

Please cite this article in press as: Polizzi, P.S., et al. Metallothioneins pattern during ontogeny of coastal dolphin, Pontoporia blainvillei, from Argentina. Mar. Pollut. Bull. (2014), http://dx.doi.org/10.1016/j.marpolbul.2013.10.037 
Table 2

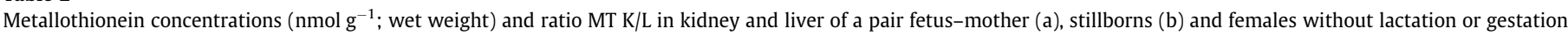
evidences (d) of Franciscana dolphin, Pontoporia blainvillei.

\begin{tabular}{|c|c|c|c|c|c|}
\hline Area & Dolphin & Kidney & Liver & $\mathrm{K} / \mathrm{L}$ & Observations \\
\hline \multirow{3}{*}{ Marine } & Fetus a & 27.8 & 89.4 & 0.3 & Female \\
\hline & Mother a & 41.7 & 66.1 & 0.6 & Gestating female, mother of Fetus 1 \\
\hline & \multicolumn{5}{|c|}{ Marine adult females media d: kidney: 37.7; liver: 42.5; K/L: 0.9} \\
\hline \multirow[t]{4}{*}{ Estuarine } & Fetus b & 20.6 & 21.3 & 1.0 & Male, evidence of spontaneous abortion \\
\hline & Fetus b & 64.7 & 28.3 & 2.3 & Male, evidence of spontaneous abortion \\
\hline & Fetus b & 44.0 & 56.4 & 0.8 & Male, evidence of spontaneous abortion \\
\hline & \multicolumn{5}{|c|}{ Estuarine adult females media d: kidney: 40.0 ; liver: $30.5 ; \mathrm{K} / \mathrm{L}: 1.3$} \\
\hline
\end{tabular}

$(p>0.05)$. For each age class and geographical group, renal concentrations of MTs were similar than those from liver (Fig. 2A and B). Mean levels of MTs in both tissues showed a decreasing trend from calves to adults in both marine and estuarine dolphin groups, although these differences were not significant $(p>0.05)$. Moreover, average MTs concentrations in juvenile (kidney: $45.1 \pm 16.5$ nmoles $\mathrm{g}^{-1}$; liver: $47.3 \pm 15.0$ nmoles $\mathrm{g}^{-1}$ ) and adult dolphins from marine area (kidney: $39.2 \pm 16.2$ nmoles $^{-1}$; liver: $41.4 \pm 14.5$ nmoles $^{-1}$ ) exhibited higher levels than those found in estuarine individuals (juvenile kidney: $39.9 \pm 17.3$ nmoles $\mathrm{g}^{-1}$;

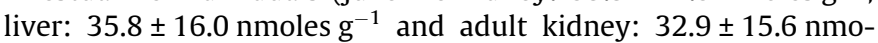
les $\mathrm{g}^{-1}$; liver: $24.9 \pm 12.3$ nmoles $\mathrm{g}^{-1}$ ). Some calves, juveniles and adults of Franciscana dolphins presented higher concentrations than mean values of their own age class, mainly in kidney of both geographical groups (Fig. 2A and B); in fact, they correspond to the highest levels found in the species.

Ratios of MTs concentrations of liver-kidney (MT K/L) were determined. Estuarine dolphins presented ratios of $1.2( \pm 0.4)$ and $1.3( \pm 0.2)$ for juveniles and adults, respectively; instead, marine dolphins showed ratios of $1.0( \pm 0.4)$ in juveniles and $1.1( \pm 0.7)$ in adults.

Zinc concentrations were higher than those of copper, and hepatic levels were higher than those of kidney for all age classes and geographic groups (Fig. 2C-F); although both metals presented the same distribution pattern by age class, tissues and geographic group, Hepatic fetal levels were the highest found for the analyzed dolphins. Moreover, the mean concentrations of $\mathrm{Zn}$ and $\mathrm{Cu}$ in kidney of estuarine dolphins were similar between juveniles and adults; while there was a decrease with age in marine organisms. Related to $\mathrm{Cu}$ in liver, adults presented higher levels than juveniles, even though a significant difference was found only in estuarine geographic group $(Z:-2.63493, p=0.008416)$. In contrast, the liver did not show a variation for the mean concentrations of $\mathrm{Zn}$, in dolphins from both geographic groups.

Renal and hepatic concentrations of MTs do not correlate to those levels of $\mathrm{Cu}$ and $\mathrm{Zn}$, in both estuarine $\left(r^{2}=0.0001-0.0360, p>0.05\right)$ and marine $\left(r^{2}=0.061-0.3233, p>0.05\right)$ groups. They not showed some correlation with those Cd levels reported previous to this study (Polizzi et al., 2013) in the same dolphins analyzed here (estuarine, $r^{2}=0.0075-0.1977, p>0.05$; marine, $r^{2}=0.0832-0.0343, p>0.05$ ).

As mentioned above, the marine fetus showed the highest hepatic MTs concentration found in the both geographic groups (Table 2). This level was 1.4 times higher than her mother, while renal concentrations were 0.7 time lower. The mother presented hepatic concentration 1.6 times higher than those found in marine females without evidence of pregnancy, while in kidney the values were similar. With regard to fetuses from estuarine geographical group (unfortunately they have not an associated mother due to correspond to spontaneous abortions), they showed different MTs concentrations than the marine fetus (see Table 2).

\section{Discussion}

Early studies on MTs in marine mammal were published in the 1970 s, and they were in pinnipeds, Callorhinus ursinus - Northern fur seal, Halichoerus grypus - Grey seal - (Olafson and Thompson, 1974), and Zalophus californianus californianus - California sea lion - (Lee et al., 1977); and in 1980 they were also in cetacean, Physeter macrocephalus - Sperm whale - (Ridlington et al., 1981), Monodon monoceros - Narwhal - (Wagemann and Muir, 1984), Stenella coeruleoalba - Striped dolphin - (Kwohn et al., 1986, 1988). The paucity of information about MTs in this biological group is associated with the difficulty to obtain samples in suitable conditions of conservation for this kind of analysis. Furthermore, catch of marine mammals in some countries such as Argentina, is legally forbidden, whereby the sampling is closely associated with bycatch and/or stranding. Even these, only catch samples, such as those analyzed here, are possible to use for the evaluation of MTs, due to dolphins were obtained immediately after capture. In the case of $P$. blainvil$l e i$, MTs information is null, recording no reports throughout the geographical distribution of the species.

The MTs are involved in the homeostatic processes to engage $\mathrm{Cu}$ and $\mathrm{Zn}$ (Klaassen, 2001), and the protection against heavy metal toxicity, such as Cd, and oxidative stress detoxification (Carpene et al., 2007; Higashimoto et al., 2009; Klaassen, 2001). In marine mammals they were associated with the homeostasis of essential metals and defenses of Cd effects, in both pinnipeds (Ikemoto et al., 2004a; Pillet et al., 2002; Sonne et al., 2009; Teigen et al., 1999) and cetaceans (Das et al., 2002, 2004, 2006; Falconer et al., 1983; Ikemoto et al., 2004b). Therefore, metallothioneins are considered as valid biomarkers in medicine (Carpene et al., 2007) and environmental studies (Blackmore and Wang, 2004; Teigen et al., 1999; Sheehan et al., 1995; Sonne et al., 2009). Moreover, they are induced and synthesized de novo when the natural levels are surpassed (Haux and Forlin, 1988; Olsson et al., 1987).

In Franciscana dolphin, it is evident that renal and hepatic concentrations of MTs are similar, regardless of geographical group analyzed. Furthermore, in both groups and tissues, there is a high variability in concentrations within each age class, suggesting a significant individual variation in the sampled populations. Notwithstanding those similarities, some Franciscana dolphins presented MT levels outside of the range, mainly in kidney of juveniles and adults. Similar situations were reported in pinnipeds (Sonne et al., 2009) and humans (Allan et al., 2000; Liu et al., 2007; Wu et al., 2000).

Levels of $\mathrm{Cu}$ and $\mathrm{Zn}$ in Franciscana dolphin were similar to those previously reported by Marcovecchio et al. (1990) and Gerpe et al. (2002) for Argentine waters, and by Lailson-Brito et al. (2002) for Brazilian waters. Besides, Law et al. (1991) reported a range of active regulation of both metals in liver, being from $3-30 \mu \mathrm{g} \mathrm{g}^{-1}$ for $\mathrm{Cu}$ (a factor of 10) and 20-100 $\mu \mathrm{g} \mathrm{g}^{-1}$ for $\mathrm{Zn}$ (a factor of 5), approximately. Organisms with levels outside of these ranges, would indicate that the mechanisms of regulation could be impaired (Law et al., 1991; Wood and Van Vleer, 1996). The pattern distribution of metals and tissues were zinc > copper and liver > kidney, and they were also found for Franciscana dolphin in previous studies, and for other species of cetaceans (Wagemann and Muir, 1984, for several species; Tursiops truncatus - Bottlenose dolphin, Wood and Van Vleer, 1996; Law et al., 1992, Physeter macrocephalus 
[P. catodon], Law et al., 1996). Zinc is an essential micronutrient for normal growth and development, such as copper (Prohaska and Gybina 2004), which is necessary for the function of more than 300 enzyme systems of mammals, regulating metabolic processes (Tapiero and Tew, 2003). Reports in cetacean (Law et al., 1992, for several species; Wood and Van Vleer, 1996, for Bottlenose dolphins), and pinniped species (Law et al., 1992, for grey seal and common seal - Phoca vitulina; Teigen et al., 1999, grey seal), suggested that concentrations of copper decrease during the first year of life and are followed by the maintenance of fairly constant concentrations throughout an animal's life. Franciscana dolphin presented the same relationship from fetuses to calves, meaning the first year of life, showing an increase in mean values from juveniles to adults in liver but not in kidney. Similar pattern for both fetus and calf age classes was reported previously for the same species in Argentine waters (Gerpe et al., 2002), but adults contained the highest concentrations of $\mathrm{Cu}$ and $\mathrm{Zn}$, followed by juveniles and calves in decreasing order. Therefore, and in contrast with our results, Gerpe et al. (2002) found an age-related accumulation of both metals in the species. Robbins (1983) postulated that mammalian milk is characterized by low contents of copper; therefore, it is likely to be a dilution effect associated with growth in mass after birth combined with a decreased supply of copper. Otherwise, decrease of copper levels in liver neonate was found in Tursiops truncaturs (Wood and Van Vleer, 1996) and in newborn human during the first year of life (Aaseth and Norseth, 1986). The declines of essential metal concentrations from fetus to calves of Franciscana dolphin, was in general terms accompanied with a decrease of hepatic levels of MTs. These outcomes were also reported as a dilution effect of this protein in young Grey seals (H. grypus, Teigen et al., 1999).

Although MTs values showed no clear relationship with the concentrations of $\mathrm{Cu}$ and $\mathrm{Zn}$, but there was a trend, regardless of geographical group, to decrease the concentrations of MTs from juveniles to adults. These results are in agreement with the information provided by Teigen et al. (1999) for H. grypus, Wood and Van Vleer (1996) for Tursiops truncatus, and those by Andrews et al. (1984) and Chan and Cherian (1993) for terrestrial mammals. Even it has been proposed that the capacity of renal tissues to produce MT may be decreasing in old age due to less efficient protein synthesis (Nordberg, 1998). Although an increase of MT levels with age was reported for pinnipeds - (Phoca hispida - ringed seal, $P$. groenlandica - harp seal - and Cystophora cristata - hooded seal, Sonne et al., 2009; H. grypus, Teigen et al., 1999 and Phoca vitulina, Tohyama et al., 1986), but they were closely associated with high concentrations of cadmium. Anyway, cadmium concentrations reported by these authors were higher than those published in the dolphins analyzed here by Polizzi et al. (2013). The maximum concentration of cadmium found in kidney was $14.87 \mu \mathrm{g} \mathrm{g}^{-1}$ and in liver $9.7 \mu \mathrm{g} \mathrm{g}^{-1}$ (wet weight). Furthermore, these levels are lower than those reported as values from which toxic effects may be manifested, liver $20 \mu \mathrm{g} \mathrm{g}^{-1}$ and kidney $200 \mu \mathrm{g} \mathrm{g}^{-1}$ (Law et al., 1996). Related to its accumulation processes, renal concentrations in marine dolphins increased since trophic independence (from 1 year old). Meanwhile, the liver of both marine and estuarine dolphins presented recently accumulation with age from the 6 years old. Despite this difference in accumulation patterns, they are not reflected in the concentrations and/or patterns of MTs. The behavior of MTs in P. blainvillei could indicate that levels found do not correspond to responses to the presence of $\mathrm{Cd}$ in tissues, being that this is a potent inducer of them (Das et al., 2000; Goyer and Clarkson, 2001; Law et al., 1992). Moreover, the environment inhabited by the estuarine group of Franciscana dolphin is influenced by the La Plata River, which is recognized as a high impact environment containing contaminants that can induce the synthesis of MTs. However, levels of MTs in estuarine dolphins do not exceed those found in the marine group. These results suggest that the potential stressors present in La Plata River estuary do not cause impact on the induction of these proteins. It is evident that concentrations of MTs in the species would be a consequence of $\mathrm{Cu}$ and $\mathrm{Zn}$ levels in liver and kidney of both geographical groups, as a result of their physiological function in the homeostasis of these essential metals. Furthermore, the body condition index, in both marine and estuarine Franciscana dolphins, evidenced no abnormalities; indeed they would indicate a good health status. These ratios were close to 1 , and were consistent with results obtained in previous studies for dolphins of the same area (Rodríguez et al., 2002).

Fetal period is characterized by a high metabolic rate, elevated development and growth, and high amounts of nutrients, such as $\mathrm{Zn}$ and Cu, are involved, (Mc Ardle and Ashworth, 1999). During this stage relevant processes are presented, from cell proliferation to organ differentiation (Dorea, 2000; Law, 1995), and relatively high levels of MTs associated to $\mathrm{Zn}$ and $\mathrm{Cu}$ are present in the liver (López de Romaña et al., 2011; Murillo-Fuentes et al., 2010). The marine fetus (in the womb of her mother) presented higher metal and MT levels, mainly in liver, than mean values of the rest of dolphins, even of those of estuarine averages (see Table 2). Similar results, where fetuses have much higher concentrations than those corresponding to their mothers, were previously reported in $S$. coeruleoalba (Honda et al., 1982), Phocoenoides dalli - Dall's porpoise - (Fujise et al., 1988); Phocoena phocoena - harbour porpoise - (Law et al., 1992) and H. grypus (Teigen et al., 1999). This information is in accordance with the increase transfer of $\mathrm{Zn}$ from mother to fetus during pregnancy found in $H$. grypus (Teigen et al., 1999). In contrast, the only report about fetus in Franciscana dolphin in Argentine water, found that $\mathrm{Cu}$ and $\mathrm{Zn}$ concentrations were lower than those found in their mothers (Gerpe et al., 2002). In the estuarine group, the stillborns presented higher metal concentrations than mean values of females, while MT levels were variable, above and below of the average of females. These dolphins are the result of spontaneous abortions, and being these relevant situations of stress, probably it was the cause of the lack of a defined pattern regarding adult females of this group geographic. In relation to the pregnant female, coincidentally with previous studies in pregnant women (Mc Ardle and Ashworth, 1999) and rats (Piletz et al., 1983), MT concentrations are higher than nonpregnant females.

Finally and based on the Zn, Cu and MTs information obtained in P. blainvillei in connection with body condition indexes, it is can be said that analyzed dolphins in this study correspond to healthy organisms, and that those levels correspond to background physiological values.

\section{Conclusions}

Considering that as the ratios MT K/L were within normal ranges, MT levels showed no differences between the two analyzed geographic groups and potentially exposed to environmental stressors, and the distribution pattern of concentrations decreasing from fetuses to adult relating to organisms with low or null impact, it is feasible to suggest that MT levels in P. blainvillei correspond to physiological ranges for the species, and they are closely related to homeostasis processes for the regulation of $\mathrm{Zn}$ and $\mathrm{Cu}$ levels, according to its ontogenetic changes.

The information found here is the first report on metallothioneins in Franciscana dolphin, a species that has been classified as Vulnerable A3d by the International Union for Conservation of Nature (IUCN), and can be considered as baseline data for future studies and those related to its conservation. 


\section{Acknowledgements}

The study was funded by the following grants: EXA 523/10 and EXA 592/12 from Mar del Plata University, and PIP 2010/0348 from CONICET. We gratefully acknowledge to fishermen: Sebastián Martín, Miguel Marchi, Lucas Mulder, Luis Ramos, José Arce and Florencia Spina for their valuable cooperation during sampling. We thank to PhD. Francesco Dondero for his help in MTs determination, Renzo Biondo for his help during $\mathrm{Cu}$ and $\mathrm{Zn}$ cuantification, Teresa Gomez for the company during necropsy and PhD. Number of CITES: 31714-15-16-17. These results are part of the Ph.D. Thesis of Paula Polizzi.

\section{References}

Aaseth, J., Norseth, T., 1986. Copper, . second ed.. In: Friberg, L., Nordberg, G.F., Vouk, V.B. (Eds.), Handbook on the Toxicology of Metals second ed., vol. II Elsevier, Amsterdam, pp. 233-254.

Adams, S.M., Giesy, J.P., Tremblay, L.A., Eason, C.T., 2001. The use of biomarkers in ecological risk assessment: recommendations from the Christchurch conference on Biomarkers in Ecotoxicology. Biomarkers ISSN, 1354-750X.

Allan, A.K., Hawksworth, G.M., Woodhouse, L.R., Sutherland, B., King, J.C., Beattie, J.H., 2000. Lymphocyte metallothionein mRNA responds to marginal zinc intake in human volunteers. British Journal of Nutrition 84, 747-756.

Amiard, J.C., Amiard-Triquet, C., Barka, S., Pellerin, J., Rainbow, P.S., 2006. Metallothioneins in aquatic invertebrates: their role in metal detoxification and their use as biomarkers. Aquatic Toxicology 76, 160-202.

Andrews, G., Adamson, E., Gedamu, L., 1984. The ontogeny of expression of murine metallothionein: comparison with the $\alpha$-fetoprotein gene. Developmental Biology 103, 294-303.

Bastida, R., Rodríguez, D., Secchi, E., da Silva, V., 2007. Mamíferos Acuáticos de Sudamérica y Antártida, third ed. Vazquez Mazzini, Buenos Aires.

Blackmore G, Wang WX (2004) Relationships between metallothioneins and metal accumulation in the whelk Thais clavigera. In Yamuna A, Saravana Bhavan P, Geraldine P (2012) Glutathione S-transferase and metallothionein levels in the freshwater prawn Macrobrachium malcolmsonii exposed to mercury. Journal of Environmental Biology 33: 133-137.

Bordino, P., Wells, R., Stamper, M.A. 2008. Satellite tracking of Franciscana Dolphins Pontoporia blainvillei in Argentina: preliminary information on ranging, diving and social patterns. IWC Scientific Committee Meeting, Santiago, Chile, June 2008.

Carpene, E., Andreani, G., Isani, G., 2007. Metallothionein functions and structural characteristics. Journal of Trace Elements in Medicine and Biology 21, 35-39.

Carsen, A., Perdomo, A., Arriola, M. 2003. Contaminación de Sedimentos del Río de la Plata y su Frente Marítimo. Documento FREPLATA, pp. 4.

Chan, H.M., Cherian, M.G., 1993. Mobilization of hepatic cadmium in pregnant rats. Toxicology and Applied Pharmacology 120, 308-314.

Das, K., Debacker, V., Bouquegneau, J.M., 2000. Metallothioneins in marine mammals. Cellular and Molecular Biology 46 (2), 283-294.

Das, K., Jacob, V., Bouquegneau, J.M., 2002. White-sided dolphin metallothioneins: purification, characterization and potential role. Comparative Biochemistry and Physiology Part C 131, 245-251.

Das, K., Siebert, U., Fontaine, M., Jauniaux, T., Holsbeek, L., Bouquegneau, J.M., 2004. Ecological and pathological factors related to trace metal concentrations in harbour porpoises Phocoena phocoena from the North Sea and adjacent areas. Marine Ecology Progress Series 281, 283-295.

Das, K., De Groof, A., Jauniaux, T., Bouquegneau, J.M., 2006. Zn, Cu, Cd and Hg binding to metallothioneins in harbour porpoises Phocoena phocoena from the southern North Sea. Bio Med Central Ecology 6 (2), 1-7.

Denuncio, P., Bastida, R., Danilewicz, D., Moron, S., Rodríguez Heredia, S., Rodríguez, D., 2013. Calf chronology of the franciscana dolphin: birth, lactation and onset on feeding ecology in coastal waters of Argentina. Aquatic Mammals 39, 73-80. Dorea, J.G., 2000. Zinc in human milk. Nutrition Research 20, 1645-1687.

Falconer, C.R., Davies, I.M., Topping, G., 1983. Trace metals in the common porpoise Phocoena phocoena. Marine Environmental Research 8, 119-127.

Fujise, Y., Honda, K., Tatsukawa, R., Mishima, S., 1988. Tissue distribution of heavy metals in Dalls porpoise in the northwestern Pacific. Marine Pollution Bulletin 19 (5), 226-230

Gerpe, M.S., Rodríguez, D.H., Moreno, V.J., de Bastida, R., Moreno, J.A.E., 2002. Accumulation of heavy metals in the Franciscana (Pontoporia blainvillei) from Buenos Aires Province, Argentina. The Latin American Journal of Aquatic Mammals 1, 95-106.

Gervais, P., d'Orbigny, A., 1844. Mammalogie. Bulletin de la Société Philomathique, Paris.

Goyer, R.A., Clarkson, T.W., 2001. Toxic effects of metals. In: Klaassen, C.D. (Ed.), Casarett and Doulĺs Toxicology. The Basic Science of Poisons. Mc Graw-Hill Co., USA, pp. 811-868.

Harrison, R.J., Bryden, M.M., McBrearty, D.A., Brownell Jr., R.L., 1981. The ovaries and reproduction in Pontoporia blainvillei (Cetacea: Platanistidae). Journal of Zoology 193, 563-580.
Haux, C., Forlin, L., 1988. Biochemical methods for detecting effects of contaminants on fish. AMBIO 17, 376-380.

Higashimoto, M., Isoyama, N., Ishibashi, S., Inoue, M., Takiguchi, M., Suzuki, S., Ohnishi, Y., Sato, M., 2009. Tissue-dependent preventive effect of metallothionein against DNA damage in dyslipidemic mice under repeated stresses of fasting or restraint. Life Sciences 84, 569-575.

Honda, K., Yatsukawa, R., Fuhiyama, Q., 1982. Distribution characteristics of heavy metals in the organs and tissues of striped dolphin, Stenella coeruleoalba. Agricultural Biology and Chemistry 46, 3011-3021.

Hylland, K., Haux, C., Hogstrand, C., Sletten, K., Andersen, R.A., 1994. Properties of cod metallothionein, its presence in different tissues and effects of $\mathrm{Cd}$ and $\mathrm{Zn}$ treatment. Fish Physiology and Biochemistry 13, 81-91.

Ikemoto, T., Kunito, T., Watanabe, I., Yasunaga, G., Baba, N., Miyazaki, N., Petrov, E.A. Tanabe, S., 2004a. Comparison of trace element accumulation in Baikal seals (Pusa sibirica), Caspian seals (Pusa caspica) and northern fur seals (Callorhinus ursinus). Environmental Pollution 127, 83-97.

Ikemoto, T., Kunito, T., Anan, Y., Tanaka, H., Baba, N., Miyazaki, N., Tanabe, S., 2004b. Association of heavy metals with metallothionein and other proteins in hepatic cytosol of marine mammals and seabirds. Environmental Toxicology and Chemistry 23 (8), 2008-2016.

Kasuya, T., Brownell, R.L., 1979. Age determination, reproduction, and growth of Franciscana dolphin, Pontoporia blainvillei. The Scientific Reports of the Whales Research Institute 31, 45-67.

Klaassen, C. (Ed.), 2001. Casarett and Doull's Toxicology: The Basic Science of Poisons. Mc Graw Hill Professional, New York, 1236 pp.

Kwohn, Y.T., Yamazaki, S., Okubo, A., Yoshimura, E., Tatsukawa, R., Toda, S., 1986 Isolation and characterization of metallothionein from kidney of striped dolphin, Stenella coeruleoalba. Agricultural Biology and Chemistry 50, 2881 2885.

Kwohn, Y.T., Okubo, A., Hirano, H., Kagawa, H., Yamazaki, S., Toda, S., 1988. Primary structure of striped dolphin renal metallothionein II. Agricultural Biology and Chemistry 52, 837-841.

Lailson-Brito, J., Azeredo, M.A.A., Malm, O., Ramos, R.A., Di Beneditto, A.P.M. Saldanha, M.F.C., 2002. Trace metals in liver and kidney of the Franciscana (Pontoporia blainvillei) from the northern coast of Río de Janeiro State, Brazil. The Latin American Journal of Aquatic Mammals 1, 107-114.

Law, R.J., 1995. Metals in marine mammals. In: Environmental Contaminants in Wildlife. British Crown Press, pp. 357-376 (Chapter 15).

Law, R.J., Fileman, C.F., Hopkins, A.D., Baker, J.R., Harwood, J., Jackson, D.B., Kennedy, S., Martin, A.R., Morris, R.J., 1991. Concentrations of trace metals in the livers of marine mammals (seals, porpoises and dolphins) from waters around the British Isles. Marine Pollution Bulletin 22, 183-191.

Law, R.J., Jones, B.R., Baker, J.R., Kennedy, S., Milne, R., Morris, R.J., 1992. Trace metals in the livers of marine mammals from the welsh coast and the Irish Sea. Marine Pollution Bulletin 24 (6), 296-304.

Law, R.J., Stringer, R.L., Allchin, C.R., Jones, B.R., 1996. Metals and Organochlorines in Sperm Whales (Physeter macrocephalus) stranded around the North Sea during the 1994/1995 winter. Marine Pollution Bulletin 32 (1), 72-77.

Lee, S.S., Mate, B.R., Von Der Trenck, K.T., Rimerman, R.A., Buhler, D.R., 1977 Metallothionein and the subcellular localization of mercury and cadmium in the California sea lion. Comparative Biochemistry and Physiology 57 (C), 45-53.

Liu, J., Cheng, M.L., Yang, Q., Shan, K.R., Shen, J., Zhou, Y., Zhang, X., Dill, A.L., Waalkes, M.P., 2007. Blood metallothionein transcript as a biomarker for metal sensitivity: low blood metallothionein transcripts in arsenicosis patients from guizhou, china. Environmental Health Perspectives 115 (7), 1101-1106.

López de Romaña, D., Olivares, M., Uauy, R., Araya, M., 2011. Risks and benefits of copper in light of new insights of copper homeostasis. Journal of Trace Elements in Medicine and Biology 25, 3-13.

Marcovecchio, J.E., Moreno, V.J., Bastida, R.O., Gerpe, M.S., Rodriguez, D.H., 1990. Tissue distribution of heavy metals in small cetaceans from the Southwestern Atlantic Ocean. Marine Pollution Bulletin 21 (6), 299-304.

Mc Ardle, H.J., Ashworth, C.J., 1999. Micronutrients in fetal growth and development. British Medical Bulletin 55, 499-510.

Mendez, M., Rosenbaum, H.C., Bordino, P., 2008. Conservation genetics of the Franciscana dolphin in Northern Argentina: population structure, by-catch impacts, and management implications. Conservation Genetics 9, 429-435.

Mendez, M., Rosenbaum, H.C., Subramaniam, A., Yackulic, C., Bordino, P., 2010 Isolation by environmental distance in mobile marine species: molecular ecology of Franciscana dolphins at their southern range. Molecular Ecology 19, 2212-2228.

Murillo-Fuentes, M., Artillo, R., Ojeda, M.L., Murillo, L., Carreras, O., 2010. Different effects on zinc redistribution if ethanol is consumed before or immediately after birth. Journal of Trace Elements in Medicine and Biology 24, 200-206.

Nordberg, M., 1998. Metallothioneins: historical review and state of knowledge Talanta 46, 243-254.

Olafson, R.W., Thompson, J.A., 1974. Isolation of heavy metal binding proteins from marine vertebrates. Marine Biology 28, 83-86.

Olsson, P.E., Haux, C., Forlin, L., 1987. Variations in hepatic metallothionein, zinc and copper levels during an annual reproductive cycle in rainbow trout, Salmo gairdneri. Fish Physiology and Biochemistry 3, 39-47.

Panebianco, M.V., Negri, N.F., Cappozzo, H.L., 2012. Reproductive aspects of male franciscana dolphins (Pontoporia blainvillei) off Argentina. Animal Reproduction Science 131, 41-48.

Piletz, J.E., Andersen, R.D., Birren, B.W., 1983. Metallothionein synthesis in foetal, neonatal and maternal rat liver. European Journal of Biochemistry 131, 489495. 
Pillet, S., Fournier, M., Measures, L.N., Bouquegneau, J., Cyr, D.G., 2002. Presence and regulation of metallothioneins in peripheral blood leukocytes of grey seals. Toxicology and Applied Pharmacology 185, 207-217.

Pinedo, M.C., Hohn, A.A., 2000. Growth layer patterns in teeth from the Franciscana, Pontoporia blainvillei: developing a model for precision in age estimation. Marine Mammals Science 16, 1-27.

Polizzi, P.S., Chiodi Boudet, L.N., Romero, M.B., Denuncio, P.E., Rodríguez, D.H., Gerpe, M.S., 2013. Fine scale distribution constrains cadmium accumulation rates in two geographical groups of Franciscana dolphin from Argentina. Marine Pollution Bulletin 72 (19), 41-46.

Prohaska, J.R., Gybina, A.A., 2004. Intracellular copper transport in Mammals. American Society for Nutritional Sciences. Journal of Nutrition 134, 1003-1006.

Reeves, R.R., Dalebout, M.L., Jefferson, T.A., Karczmarski. L., Laidre, K., O'CorryCrowe. G., Rojas-Bracho. L., Secchi, E.R., Slooten. E., Smith. B.D., Wang. J.Y., Zerbini. A.N., Zhou. K. 2012. Pontoporia blainvillei, In: IUCN 2010. IUCN Red List of Threatened Species.

Ridlington, J.W., Chapman, D.C., Goeger, D.E., Whanger, P.D., 1981. Metallothionein and $\mathrm{Cu}$-chelatin: characterization of metal-binding proteins from tissues off our marine animals. Comparative Biochemistry and Physiology 70 (B), 93-104.

Robbins, D.T., 1983. Wildlife Feeding and Nutrition. Academic Press, San Diego, USA

Rodríguez, D., Rivero, L., Bastida, R., 2002. Feeding ecology of the Franciscana (Pontoporia blainvillei) in marine and estuarine waters of Argentina. Latin American Journal of Aquatic Mammals 1 (1), 77-94.

Roesijadi, G., 1996. Metallothionein induction as a measure of response to metal exposure in aquatic animals. Environmental Health Perspectives 102 (12), 91

Secchi, E.R., Wang, J.Y., 2002. Assessment of the conservation status of a Franciscana (Pontoporia blainvillei) stock in the Franciscana Management Area III following the IUCN Red List Process. Latin American Journal of Aquatic Mammals 1 (1), 183-190.

Secchi, E.R., Danilewicz, D., Ott, P.H., 2003. Applying the phylogeographic concept to identify franciscana dolphin stocks: implications to meet management objectives. Journal of Cetacean Research Management 5, 61-68.

Sheehan D, Mc Intosh J, Power A, Fitzpatrick PJ (1995) Drug metabolizing enzymes of mussels as bioindicators of chemical pollution. In Yamuna A, Saravana Bhavan P, Geraldine P (2012) Glutathione Stransferase and metallothionein levels in the freshwater prawn Macrobrachium malcolmsonii exposed to mercury. Journal of Environmental Biology 33: 133-137.

Siciliano, S., 1994. Review of small cetaceans and fishery interactions in coastal waters of Brazil. Reports International Whaling Communication 15, 241-250.

Sonne, C., Aspholm, O., Dietz, R., Andersen, S., Berntssen, M.H.G, Hylland, K., 2009. A study of metal concentrations and metallothionein binding capacity in liver, kidney and brain tissues of three Arctic seal species. Science of the Total Environment 407, 6166-6172.

Tapiero, H., Tew, K.D., 2003. Trace elements in human physiology and pathology: zinc and metallothioneins. Biomedicine \& Pharmacotherapy 57, 399-411.

Teigen, S.W., Andersen, R.A., Daae, H.L., Skaare, J.U., 1999. Heavy metal content in liver and kidneys of Grey Seals (Halichoerus grypus) in various life stages correlated with metallothionein levels: some metal-binding characteristics of this protein. Environmental Toxicology and Chemistry 18, 2364-2369.

Tohyama, C., Himeno, S.I., Watanabe, C., Suzuki, T., Morita, M., 1986. The relationship of the increased level of metallothionein with heavy metal levels in the tissue of the harbor seal (Phoca vitulina). Ecotoxicology and Envirnmental Safety 12 (1), 85-94.

Viarengo, A. Ponzano, E. Dondero, F, Fabbrih, R, 1997. A simple spectrophotometric method for metallothionein evaluation in marine organisms: an application to mediterranean and antarctic molluscs. Marine Environmental Research 14 (1), 69-84.

Wagemann, R., Muir, D.C.G., 1984. Concentrations of heavy metals and organochlorines in marine mammals of northern waters: overview and evaluation. Canadian Technical Report Fisheries and Aquatic Science 1279, 97.

Wood, C. Van Vleer, E. 1996. Cooper, cadmium and zinc in liver, kidney and muscle tissues of bottlenose dolphins (Tursiops truncatus) stranded in Florida. Marine Pollution Bulletin 32, 886-889.

Wu, M.T., Demple, B., Bennett, R.A.O., Christiani, D.C., Fan, R., Hu, H., 2000 Individual variability in the zinc inductibility of metallothionein- $\mathrm{IL}_{\mathrm{A}} \mathrm{mRNA}$ in human lynphocytes. Journal of Toxicology and Environmental Health, Part A: Current Issues 61 (7), 553-567.

Yang, J., Miyazaki, N., 2003. Moisture content in Dall's porpoise (Phocoenoides dalli) tissues: a reference base for conversion factors between dry and wet weight trace element concentrations in cetaceans. Environmental Pollution 121, 345347. 